\title{
Commentary: When Tony met Bobby
}

\author{
By
}

Leigh Sparks, Institute for Retail Studies, University of Stirling, Stirling, FK9 4LA 


\section{Commentary: When Tony met Bobby}

In June 1999, Wal-Mart intervened spectacularly in an agreed merger between Asda and Kingfisher by paying $£ 6.7 \mathrm{bn}$ to takeover Asda outright. Reactions ranged dramatically (Whysall 2001); this was the death-knell of British retailing or the redemption of British consumers. Whatever the view, Wal-Mart buying a major retailer such as Asda, and in such a significant European market, was a landmark in the globalisation of retailing.

One issue around this takeover attracted considerable speculation at the time and has been the focus of discussion specifically (Hallsworth and Clarke 2001) and generally (Burt and Sparks 2001) in articles in this journal. Some months previous to the takeover, a meeting apparently took place in Downing Street between the Prime Minister and Wal-Mart. The very fact this meeting occurred, and at that time, is intriguing. Secrecy surrounding the meeting increased speculation over the contents of any discussion. It was raised in Parliament and during investigations on retailing by the Select Committee on the Environment, Transport and Regional Affairs. Over time however the meeting has faded from public attention and consideration. Yet, it still remains potentially significant. The introduction from January 2005 of the Freedom of Information Act potentially opened a window on this previously 'secret' meeting. This commentary concerns the meeting itself and the use of the Freedom of Information Act to obtain information about it. It raises questions about lobbying, secrecy and retail change and is another window on Pal and Medway's (2008) commentary on 'working the system'.

\section{What is Known Publicly about 'The Meeting'?}

The potential entry of Wal-Mart to the UK was much debated in the late 1990s though publically denied by Wal-Mart. Rumours about a meeting between Wal-Mart and the British 
Government began to surface in mid-April 1999. After initial stonewalling, the meeting itself was confirmed to have taken place, although no details were provided. Over time various reports circulated in the press, making a variety of claims about those present, its origins and timing and what was discussed:

(a) Whilst knowledge of the meeting emerged in April 1999, the reports variously record it as taking place in late February and early March. Only one report gives a specific date, Thursday 25 February. In answer to a Parliamentary Question in May 1999, Tony Blair, then Prime Minister, indicated the meeting was 'about a month ago'. In an answer to a Parliamentary Question in April 2001, the Prime Minister refused to reveal the exact date.

(b) The attendees are variously described. Wal-Mart is represented by 'senior executives', 'a chief' or 'a delegation'. Most reports mention Bob Martin, then President and Chief Executive Officer of Wal-Mart's International Division, though The Times claims Lee Scott, then Chief Operating Officer of Wal-Mart Inc was present. Initially the meeting was described as being with 'top British Government officials' but this soon changed to being the Prime Minister. The most detailed press report of the meeting (Mail on Sunday 20 June 1999) claims that it was 'engineered' and attended by the Liberal Democrat peer Lord Jacobs. Tony Blair was supported apparently by Geoff Norris, a member of the Number 10 policy unit. Other reports at this time indicate another unnamed adviser was present. The Prime Minister refused to reveal the attendees in an answer to a Parliamentary Question in June 1999. 
(c) Most accounts of the meeting follow the line of a briefing by a Number 10 spokesman when news of the meeting emerged. He (unnamed in the British Press but identified as a Peter Wilkinson in the Arkansas press) is quoted:

"He (Bob Martin) was coming through Europe at the time and requested a short courtesy call with the Prime Minister. My understanding is that it was a brief exchange of views on the economic situation, both here and wider, and no concrete business was discussed." (emphasis added)

At other times the meeting was described as a 'social visit' or 'an exchange of pleasantries'. The Prime Minister, in answer to a Parliamentary Question in May 1999, described it as 'a short courtesy call at his (ie. Wal-Mart's) request'.

(d) Coverage of the meeting and questions raised in Parliament however have contended that issues such as the relaxation of land-use planning and the takeover of a British company must have been discussed. The Prime Minister is on record at the time as desiring greater competition and lower prices in the UK and many commentators (see Hallsworth and Clarke 2001) describe grave fears about the potential relaxation of land-use planning at this time. Indeed the Select Committee on the Environment, Transport and Regional Affairs specifically examined the issue of Wal-Mart's takeover of Asda and the possible discussion of planning issues at the 'Martin/Blair' meeting. The committee chairwoman stated:

"We were given straightforward assurances that planning was not discussed. We must accept the evidence and we don't assume people are lying." (Press Association, 11.1.2000)

Ministers Nick Raynsford and Richard Caborn have categorically denied that planning was discussed at the meeting. Nick Raynsford however did say in evidence to the Select Committee (27.10.1999, paragraph 165) that the meeting did discuss Wal-Mart's proposed acquisition of Asda. This is rather odd, as when the meeting 
convened there was no such proposal and Wal-Mart denied any interest for some months later.

\section{The Freedom of Information Act}

In January 2005 the Freedom of Information Act came into force in the UK and enshrined a public right to know about 'governmental' affairs, subject to certain exemptions. Given the speculation and innuendoes about the 'Blair/Martin' meeting and the official line that it was a courtesy or social visit with no concrete business, the public's right to know about the meeting would seem unanswerable.

Under the Freedom of Information Act I applied to the Prime Minister's Office for the minutes of the meeting. Some three years later a copy of the note of the meeting was finally made available in response to my request. A saga of denial, evasion, and duplicity was ended by a decision notice from the Information Commissioner's Office. Failure to comply could have resulted in contempt of court proceedings against the Cabinet Office. Table 1 presents the timeline. A full copy of the Information Commissioner's notice is available (Information Commissioner's Office 2007), as is now the note of the meeting (Cabinet Office 2008).

\section{The Progress of the Request}

The request to the Prime Minister's Office on the $3^{\text {rd }}$ January 2005 asked for sight of the minutes of the meeting between Tony Blair and Bob Martin (of Wal-Mart) and others. In March 2005 the Cabinet Office rejected the request as being exempt under Section 35(1)(a) of the Freedom of Information Act 2000. They argued that the meeting related 'to the formulation or development of government policy' and concluded that 'it was not in the public interest to release this information as advice should be broadly based and there may be 
a deterrent effect on external experts or stakeholders who might be reluctant to provide advice in the future because it might be disclosed'

On receipt of this view an internal review by the Cabinet Office of this decision was requested mainly on the basis that the grounds for refusal were somewhat disingenuous and did not address the balance of the public interest. If the meeting was (according to the Prime Minister in Parliament) a social call then why was the public interest best served by maintaining secrecy?

In May 2005 the Cabinet Office responded that they had carried out a review, but confirmed their decision. They maintained their previous stance: "release of this information would have a deterrent effect on experts or stakeholders giving free and frank advice and their views to Government and that this would lead to poorer decision making. It is essential that in circumstances such as these, a business leader is able to speak to the Prime Minster freely, frankly and in confidence". Rather oddly however they also indicated that if Section 35 of the Act did not apply (development of policy) then Section 36 (2) (b) (i) and (ii) would apply (free and frank provision of advice and exchange of views).

Given the immovability of the Cabinet Office, a request was submitted in June 2005 to the Information Commissioner's Office for them to investigate the handling of the initial request, as allowed for under the Act. The request was based on:

- The contrast between the 'social call' comment and the new status of the meeting as 'formulation and development of government policy'. In passing it was noted that if the latter was now correct, then the Prime Minister was likely to have misled Parliament; 
- The switching of grounds for defending the non-release of the information between Sections of the Act;

- The passage of time and the changing retail structure which would render any 'advice' somewhat out-of-date;

- A view that if the Cabinet Office line was upheld then all meetings could be claimed to be an 'exchange of views' and thus exempt from disclosure. This would clearly defeat the purpose of the Freedom of Information Act.

Unfortunately the Information Commissioner's Office at this time was overwhelmed by complaints over decisions. The volume of cases, plus their novelty and complexity meant that my case was inactive for 15 months. It was not opened until September 2006. Even then, whilst the case was being considered, nothing happened until, in February 2007, the Cabinet Office wrote to offer a summary of the points discussed at the meeting. The summary (5 bullet points on one side of paper) was apparently provoked by the Information Commissioner's Office writing to the Cabinet Office and them in turn reviewing the case.

This was confirmed by the Information Commissioner's Office: '(we) have been attempting to obtain the information which you requested ... in order to consider whether it (the Cabinet Office) was justified in applying the exemptions'. They asked if, given the Cabinet Office had now provided a summary, whether or not the Information Commissioner's Office should continue to investigate the matter. I replied that the summary was not in my view sufficient and that the investigation should continue. 
In December 2007 the Information Commissioner's Office issued a Decision Notice (the formal decision is reproduced as Figure 1) requiring the release of the minutes within 35 working days (Information Commissioner's Office 2008). The Cabinet Office complied (allowing for Christmas and New Year) and a three page note with names and attributed comments was provided (Cabinet Office 2008).

The Decision Notice states that the Cabinet Office breached the Act by:

(a) providing a misleading summary of the meeting;

(b) failing to provide details of review procedures;

(c) delaying making decisions;

(d) failing to provide an adequate assessment of the public interest test; and

(e) inappropriately withholding information as being exempt when it was not.

Once the Information Commissioner opened the case, they made contact with the Cabinet Office. To make a decision, the Information Commissioner's Office needed to see the detailed minutes. The Cabinet Office prevaricated over this, before offering the summary. When asked to provide the full minutes they again delayed. The Information Commissioner's Office issued reminders and finally threatened to formally issue an Information Notice to obtain the minutes. Having seen both the summary and the full minutes the Information Commissioner's Office indicated that the case is not complex, the material limited and that the Cabinet Office defence of the summary is not adequate. Moreover, they criticise the Cabinet Office's weighing up of the public interest and its briefing to a qualified person (in this case two Ministers of the Cabinet Office were used) to judge public interest. 
Additionally, the Information Commissioner's Office challenged the use of varying sections of the Act by the Cabinet Office. They judged it fell under 36 (2)(b)(ii) on the 'free and frank exchange of views for deliberation'. This is significant as they then say that the minutes clearly do not provide such an 'exchange' and 'deliberation', and as such are releasable. This means that any future 'blanket' description of minutes as an 'exchange' will not be permitted.

\section{So What Does the Note Tell Us?}

The note of the meeting confirms a number of elements and raises new questions (not least when compared with their summary):

(a) The note was prepared by Owen Barder, addressed to Jonathan Powell and copied to Jeremy Heywood and Geoffrey Norris. The meeting was between Bob Martin, the Prime Minister and Lord Jacobs. In attendance were Powell, Norris and Barder. This is a top-level meeting including senior advisors.

(b) Martin commented on speculation about Wal-Mart entering the UK and said if WalMart was in Europe, then it should be in the UK'. However he indicated that 'the main obstacle to entering the UK market was zoning and planning controls - Wal-Mart had concluded that they could only come into the UK by acquisition of an existing company'.

(c) Martin's views on the UK market was that it needed Wal-Mart to trigger price wars to 'get cost out of the system ... margins were high'. He accused Tesco and Sainsbury's of being good retailers whose 'quality premium product labels had kept prices lofty'. 
(d) Tony Blair indicated that he wanted competition and innovation in markets and noted claims that prices were $30 \%$ higher in the UK than abroad and that a lot of change was needed. This was reinforced by Lord Jacobs who indicated 'possible targets for acquisition in the UK'. Owen Barder concluded that he would not be surprised if WalMart tried to acquire Asda and understood that Geoffrey Norris had reached the same conclusion. This is of course two months before Kingfisher announced its agreed merger with Asda and thus also well before Wal-Mart intervened. Publicly during March and April 1999 Wal-Mart denied any interest in Asda or the UK.

These are a note of the meeting and as such do not tell us what was actually said and what was conveyed or meant. Whilst for example they show that planning was raised by WalMart, the Prime Minister's response was in terms of innovation, competition and prices rather than on planning per se. But what was intended, meant and received during the meeting remains a mystery. How seriously planning was 'discussed' is unclear. The note is interesting but of course partial.

\section{So, Does It Matter?}

For six years prior to the Freedom of Information request the minutes of the meeting were kept secret. For a further three years the Cabinet Office sought to keep them secret despite the Freedom of Information request, using a variety of tactics including preparing a 'misleading' (Information Commissioner's Office 2008) summary of the meeting. Consideration of the 'worth' of the outcome can thus be assessed from a variety of perspectives. 
Why was so much secrecy involved? This is hard to judge, but there could be concern that the view of the government (advisers) at the meeting was that Wal-Mart was about to bid for Asda and that this was seen as beneficial in meeting government interests. One assumes that such information, which is commercially sensitive, would need to be kept secret and not acted upon at the time in any way. It may also be due to embarrassment that the government could be seen to be so dismissive of existing UK retailers and so welcoming of Wal-Mart. Naïve views of British retailing were put forward by the Prime Minister and there is a rather comical mis-attribution of a book by the founder of Wal-Mart to one 'Sam Norton' - one wonders if Tony Blair ever did get his signed copy of Sam Walton's memoirs?

It is interesting to compare the 'misleading' summary with the actual note. The comments by Bob Martin are summarised accurately except for omitting a section on Wal-Mart's success in Germany and his views on Tesco and Sainsbury keeping prices 'lofty'. His comment about margins being high has been changed in the summary to "scope to get more competition in the market'. One could interpret the note of the meeting as being more direct than the summary in 'blaming' British retailers for high prices, something the Government might not want to be made public. This is reinforced by the omission in the summary of the Prime Minister's comment about high prices in the UK, all of the remarks by Lord Jacobs and Barder's comment (and Norris' reported views) about Wal-Mart buying Asda. The summary is bland and general whereas the note reads more overtly that British retailers were a problem and that a takeover was both on the cards and a good thing.

The other element missing from the summary was a listing of those present. The Information Commissioner's Office explicitly stated that names should be revealed. They show the 'powers behind the throne', several of whom are key advisers in the Brown administration. 
This 'shadowy' lobbying and advising process is one that many businesses use (Pal and Medway 2008) and it depends on access, doorkeepers and those inside the apparatus. At this meeting, key economic and policy advisers are present, as is the less obvious figure of Lord Jacobs, though he had a long-standing position on 'rip-off Britain' and high consumer prices.

Both at the time of the meeting and subsequently it was presumed that Wal-Mart lobbied over land-use planning restrictions. Indeed they were raised in the meeting (despite previous denials) and would have impinged on people to varying degrees. In January 2008, one newspaper reported that the note of the meeting flatly contradicted the government's stated position on planning (Hope and Hall 2008). However if there was an agreement to let Asda expand and to help them by reducing planning restrictions then Asda/Wal-Mart has had to wait a long time. Asda have in the 2000s been thwarted in their attempts to expand, both generically due to planning tightening and specifically by not being allowed to take over Safeway in 2003 (Competition Commission 2003). The competition authorities in 1999/2000 did not see any problems (Competition Commission 2000). Asda has struggled to compete with Tesco (Burt and Sparks 2006). Recently however the Barker report on planning (Barker 2007) and the latest Competition Commission's report (Competition Commission 2008) have recommended the removal of the planning 'need test' and its replacement by a 'fascia test'. This would clearly favour Asda over Tesco as it would tend to operate against local domination and strong market leaders. It is hard to see how this is a direct result of the 1999 meeting, but the driver behind current proposals, that competition needs to be intensified, is one that shines through in the note of the meeting. 


\section{When Tony met Bobby ...}

The façade that this meeting was a social chat can no longer be maintained. The meeting provided a statement of intent from Wal-Mart and a welcome from the UK government. Contemporaneous statements that planning was not discussed seem half-truths at best. What the various parties took from the meeting is impossible to say, but planning and market entry as well as the potential for intensified competition leading to cheaper consumer prices did figure. Some of the advisers remain in positions of power and influence, though the two main players (Blair and Martin) have both moved on. The meeting itself remains an illustration of the interactions of business and government. Why should these be secret? They directly affect all of us. Attempts to keep such meetings private should be seen for what they are - an affront to democracy. 


\section{References}

Barker, K. (2006) Barker review of land use planning: final report - recommendations, Norwich: HMSO. Available at http://www.hmtreasury.gov.uk/media/3/A/barker finalreport051206.pdf (accessed $27^{\text {th }}$ August 2008).

Burt, S.L. and L. Sparks (2001) "The implications of Wal-Mart's takeover of Asda", Environment and Planning A, 33, 1463-87.

Burt, S.L. and L. Sparks (2003) "Power and competition in the UK retail grocery market", British Journal of Management, 14, 237-54.

Burt, S.L. and L. Sparks (2006) "ASDA: Wal-Mart in the United Kingdom”, p 245-262 of Brunn, S.D. (ed), Wal*Mart World: The World's Biggest Corporation in the Global Economy, New York: Routledge.

Cabinet Office (2008) Tony Blair's Meeting with Wal-Mart. Available at http://interactive.cabinetoffice.gov.uk/documents/walmart.pdf (accessed 27 $7^{\text {th }}$ August 2008).

Competition Commission (2000) Supermarkets: A report on the supply of groceries from multiple stores in the United Kingdom, London: TSO. Available at http://www.competitioncommission.org.uk/inquiries/completed/2000/index.htm (accessed 27th August 2008)

Competition Commission (2003) Safeway plc and Asda Group Limited (owned by Wal-Mart Stores Inc); Wm Morrison Supermarkets plc; J Sainsbury plc; and Tesco plc: A report on the mergers in contemplation, London: TSO. Available at http://www.competitioncommission.org.uk/inquiries/completed/2003/safeway/index.htm (accessed 27th August 2008)

Competition Commission (2008) Groceries Market Investigation, London: Competition Commission. Available at http://www.competition-commission.org.uk/inquiries/ref2006/grocery/index.htm (accessed 27th August 2008)

Hallsworth, A.G. and I. Clarke (2001) "Further reflections on the arrival of Wal-Mart in the United Kingdom", Environment and Planning A, 33, 1709-16.

Hope, C. and J. Hall (2008) Wal-Mart did lobby Blair over Asda. Sunday Telegraph, $28^{\text {th }}$ January 2008. Available at http://www.telegraph.co.uk/money/main.jhtml?xml=/money/2008/01/27/cnasda127.xml (accessed $27^{\text {th }}$ August 2008).

Information Commissioner's Office (2007) Freedom of Information Act 2000 (Section 50) Decision Notice FS50078471. Available at http://www.ico.gov.uk/upload/documents/decisionnotices/2007/fs_50078471.pdf (accessed $26^{\text {th }}$ August 2008)

Pal, J. and D. Medway (2008) "Commentary: Working the System", Environment and Planning A, 40, 761-5. 
Walters, S. and V. Moss (1999) Tony Blair, Wal-Mart and now the Hillary Clinton Connection. Mail on Sunday, 20 June 1999, p32-33.

Whysall, P. (2001) "Wal-Mart's takeover of Asda: what the papers said", British Food Journal, 103, 729-43. 
Table 1 : Timeline of Freedom of Information Act Request

$\underline{2005}$

January $3^{\text {rd }}$

February $7^{\text {th }}$

March $1^{\text {st }}$

$\operatorname{March} 6^{\text {th }}$

May $26^{\text {th }}$

June $3^{\text {rd }}$

$\underline{2006}$

June $27^{\text {th }}$

September $26^{\text {th }}$

$\underline{2007}$

February $23^{\text {rd }}$

March $19^{\text {th }}$

November $19^{\text {th }}$

$\underline{2008}$

January $15^{\text {th }}$
Initial Request for Minutes of Meeting.

Confirmation that information exists but notification of delay to response in order to apply 'public interest' test.

Request refused under Section 35(1)(a) as relating to 'formulation or development of government policy' and 'deterrent effect on external experts or stakeholders'.

Request for internal review of decision.

Previous decision upheld and additionally claimed Section 36(2)(b)(i) and (ii) on 'free and frank provision of advice and exchange of views' applies.

Request to Information Commissioner's Office for review of decision and process.

Apology from Information Commissioner's Office over length of time to investigate case.

Case formally opened.

Cabinet Office provides a 'summary of the points discussed' after reviewing position at request of Information Commissioner's Office.

Request to Information Commissioner's Office to determine the original complaint, as summary insufficient.

Information Commissioner's Office upholds complaint and issue decision notice to Cabinet Office to provide full copy of requested information within 35 working days.

Cabinet Office release the note of the meeting. 


\section{Figure 1: The Information Commissioner's Decision}

The Commissioner's decision is that the public authority did not deal with the request for information in accordance with the Act. The Commissioner has concluded that, in seeming but failing to provide a comprehensive summary of the information, the Cabinet Office acted in breach of section 1(1)(b). In failing to provide, in its refusal notices, details of either its own internal review procedures or of the Information Commissioner's Office the Cabinet Office breached its obligations under section 17(7) of the Act. In delaying providing its initial response and internal review decision the Cabinet Office failed to comply with the requirements of section 10(1) of the Act, which constitutes a breach of section 17(1). In failing, in its refusal notice, to identify factors in favour of disclosure of the information, or to provide an adequate assessment of the public interest test, the Cabinet Office again breached section 17(1). Finally the Cabinet Office breached section 36 by inappropriately withholding the requested information as being exempt under that section.

Source: Information Commissioner's Office (2008) 